охороняли суворо. Зрозуміти сенс вчинку Сократа, пише сучасний філософ, можна тільки виходячи 3 сократичного мислення. Лише цей тип мислення дозволяє без фальші діяти і вмирати.

К. Ясперс надає оцінку вироку Сократа Гегелем: Афіни мали рацію, бо відстоювали свою сутність, Сократ мав рацію, оскільки він сповіщав нову епоху, яка цю сутність руйнувала. К. Ясперс не поділяє такого підходу. Він вважає, що така абсолютизація конфлікту невідповідна значенню Сократа. Трансформація духу епохи не означає правоти епохи i не приміряє різні правди. Скоєне буде піддане вищому суду (i це пише представник атеїстичної філософії) [2, с. 209]. Істинне і благе, як i помилкове і нице, не можуть бути закриті маскою трагічного. Філософ переконаний, що невігластво афінського суспільства не знімає з нього і афінського держави відповідальності за смерть Сократа. Смерть Сократа в юридичному сенсі ще й розкриває цинізм, лукавство і лицемірство афінського суду - його вирок не $є$ остаточним, це вирок тільки формально. За людиною залишається вибір. Сократ помер не тому що так вирішила афінська демократична держава, а тому, що таким був його вибір. Абсолютно усвідомлено, він зробив свій вибір сам. Для того, щоб дати вірну оцінку вибору великого філософа, пише К. Ясперс, i зрозуміти його, ми повинні мислити категоріями сучасного Сократу часу.

\title{
Література:
}

1. Платон. Апологія Сократа. Діалоги / Платон - Харків: Фоліо, 2008. $349 \mathrm{c}$.

2. Ясперс К. Сократ. История философии. 2003. № 10. С. 199-218.

DOI https://doi.org/10.30525/978-9934-26-148-0-6

\section{ВІТЧИЗНЯНА ЮРИДИЧНА НАУКА: ПРОБЛЕМИ ТА ВИКЛИКИ СУЧАСНОСТІ}

\section{Карпічков В. О.}

кандидат юридичних наук, дочент кафедри теорії та історії права та держави Інституту права Київького національного університету

\author{
імені Тараса Шевченка
}

м. Київ, Украӥна

Динамічний характер сучасного життя та суперечливі суспільні реалії ставлять перед вітчизняною юридичною наукою нові складні завдання. В технократичному суспільстві, де матеріальні цінності 
витісняють духовні, а технологічний прогрес взаємообумовлюється культурним регресом, одвічні суспільні цінності весь час перебувають під реальною загрозою з боку чисельних зловмисників і шахраїв. Не дивлячись на вражаючий масив нормативно-правової бази, величезну кількість законів і міжнародних актів, компетентні урядові інституції та правоохоронні органи, ми кожного дня спостерігаємо свідоме, систематичне порушення прав і свобод людини та громадянина в Україні, що наштовхує на думку про свідоме нехтування надважливими принципами «законності», «верховенства права» та «справедливості» як пересічними учасниками суспільних відносин, так і державними службовцями. Подібна ситуація дозволяє стверджувати, що існуюча система юридичних знань потребує реформування відповідно до проблем i викликів сучасності.

Важливим завданням, що стоїть перед вітчизняною юридичною наукою на сучасному етапі, $\epsilon$ розроблення дієвих юридичних конструкцій, які б органічно поєднували у собі одвічні правові ідеї та принципи права, світовий правничий досвід, сучасне нормотворення та високі технології для побудови дієвої системи національного права 3 взаємоузгодженою і ефективною взаємодією окремих іiі елементів, а також сприяли б забезпеченню основоположних принципів «верховенства права», «справедливості», «законності», «рівності всіх перед законом» та відновленню значимості справжніх суспільних цінностей.

Як ми знаємо, існує умовний, але досить відчутний «конфлікт» між юридичною теорією і практикою. Безсумнівно, досягнення юридичної науки не можуть набути довершеного характеру, якщо не знайдуть своє застосування на практиці. Відтак, надзвичайно важливою умовою для розвитку сучасної юридичної науки $€$ переосмислення застарілих поглядів на право та упорядкування системи юридичних знань відповідно до проблем сучасного життя, зокрема до потреб учасників суспільних відносин. Варто в котре наголосити на тому, що категорії юридичної науки не є відірваними від супільного життя та правової реальності, оскільки завдяки своєму універсальному, абстрактному характеру вони можуть найбільш повною мірою визначити, охарактеризувати і відобразити сучасну існуючу правову дійсність з усіма іiі позитивними та негативними проявами, отже, за їх допомогою можливо віднайти дієвий спосіб впливу на учасників суспільних відносин з метою стимулювання «здорової» суспільної поведінки, відновлення деформованого правового світогляду та збільшення рівня правової культури в суспільстві, а відтак повернення правових цінностей з ідейної площини у практичну. За допомогою формул юридичної науки i сучасних технологічних засобів цілком можливо створити дієвий алгоритм, який дозволив би прогнозувати й попереджати всі можливі ризики, пов'язані 3 негативними правовими явищами та надавав би змогу правоохоронним 
органам діяти на випередження, щоб присікати злочинні діяння в зародку і визначати потенційних правопорушників для їх перевиховання. Поєднання сучасних технологічних засобів і потужного потенціалу юридичної науки з їі тисячолітнім надбанням надало б можливість побудувати міст між юридичною теорією та практикою, що дозволило б одвічним принципам права органічно поєднатись із сучасним життям.

Ще однією проблемою вітчизняної юридичної науки є відчутно застарілий нормативізький підхід, який тривалий час вважався домінуючим напрямом більшості юридичних досліджень, основна ідея яких була направлена на аналіз проблем чинного законодавства та шляхів його удосконалення. Однак, не дивлячись на таку, здавалося б, активну дослідницьку роботу нормативістів, за всі ці роки ми не спостерігаємо помітних позитивних зрушень, а кількість правопорушень і суспільних протиріч з роками лише збільшується. Потрібно не забувати, що для побудови справжнього громадянського суспільства до уваги мають братися не лише суто нормативні аспекти регулювання, а й власне особливості самих учасників суспільних відносин, їх правовий світогляд, менталітет, культуру та потреби. Тому, на наше глибоке переконання, вітчизняна юридична наука, має навпаки, відходити від нормативізму та визначити нові орієнтири для подальших теоретикопрактичних досліджень права. Варто приділити більшу увагу аксіологічному та антропологічному напрямкам правових досліджень, які $\epsilon$ взаємопов'язаними, оскільки право виступає суспільною цінністю, але в свою чергу, воно має на меті захищати найважливіші суспільні цінності такі як життя, здоров'я, права та свободи людей. Реалізація цих двох напрямів на практичному рівні має стати першочерговим завданням для сучасної правничої науки, оскільки лише за цієї умови вдасться подолати внутрішні протиріччя та конфлікт суспільства і держави.

До важливих проблем вітчизняної юридичної науки також можна віднести: помітну хаотичність більшості правових досліджень, відсутність чітко встановлених науково-дослідницьких критеріїв, зокрема у методології юридичних досліджень, помітний брак власних оригінальних наукових концепцій через постійне запозичення так званого «зарубіжного досвіду більш розвинених країн», тощо [1, с. 191]. Як наслідок в нашій державі законодавча i нормотворча діяльність позбавлена належної науково-концептуальної основи, а прийняті закони позбавлені практичної раціональності та віддалені від реальної суспільно-правової дійсності. Таким чином, перегляду вимагає підхід до проблематики сучасних правових досліджень, які мають бути направлені на пошук зв’язків між теорією та практикою і шляхів реального втілення одвічних ідей права у суспільне життя, в тому числі із застосуванням сучасних технологій; пошук шляхів зменшення негативних явищ правової дійсності та попередження правопорушень, а не на обгрунтування 
необхідності прийняття нових недієвих законів на зміну недолугим попереднім.

Основну причину зухвалої поведінки злочинців і постійних правопорушень слід шукати в самому корені. Цілком очевидно, що «здорова» суспільна поведінка напряму пов'язана 3 особистими якостями людини, такими як моральність, порядність, вихованість, чесність, гідність, добросовісність, повага до інших, тощо. Це означає, що витоки злочинної поведінки лежать у самій людській природі, іiі знаннях, вихованні, світогляді та цінностях. Змінити світогляд дорослої людини, привити не властиві для неї позитивні якості, навчити вихованості або повазі до інших майже неможливо, хіба що за власним бажанням самої особи. Переважна більшість таких позитивних особистісних якостей властиві людині якщо не від самого народження, то в результаті іiї навчання та виховання. Не зважаючи на всі зусилля батьків, дошкільних і шкільних закладів освіти, вищих навчальних закладів, компетентних державних інституцій та спецслужб, ніщо не може гарантувати або ж забезпечити «здорову» поведінку учасників суспільних відносин, а відтак більшість превентивних засобів попередження правопорушень не діє. Саме тому юридична наука має переглянути схему попередження правопорушень і знайти нові законні методи впливу на учасників суспільних відносин, у тому числі за допомогою інформаційних технологій, а також створити нову концепцію законних засобів протидії злочинності та методів впливу (зокрема психологічного і виховного) на населення з метою пропаганди «здорової» суспільної поведінки.

Отже, на підставі вищезазначеного, можна зробити висновок, що вітчизняна юридична наука має реагувати на проблеми i виклики сучасності, шляхом перегляду застарілих уявлень про право, відходу від нормативізму на користь антропологічного та аксіологічного підходів, встановлення чітких науково-методологічних критеріїв для юридичних досліджень, розробки концепції законних засобів протидії злочинності і попередження злочинів за допомогою психологічного та виховного впливу на населення, зокрема із застосуванням сучасних інформаційних технологій для пропаганди «здорової» суспільної поведінки, а також використовувати сучасні технологічні досягнення і багатовіковий досвід юридичної науки для поєднання теорії з практикою, що дозволило б одвічним принципам i цінностям права органічно поєднатись із сучасним суспільним життям.

\section{Література:}

1. Гуменюк T.I. Концепти функціонування сучасної юридичної науки. Підприємницттво, господарство і право. 2018. № 4. С. 188-192. 